\title{
Transliteration of Digital Gujarati Mathematical Text into Braille for Visually Impaired People
}

\author{
Nikisha B. Jariwala ${ }^{1}$ and Dr. Bankim Patel ${ }^{2}$
}

\begin{abstract}
Due to the limited availability of resources, particularly literatures in Braille text, visually impaired people are usually away from main stream of the society. Many researchers have worked on converting regular regional language text into Braille text. However, most of them have not given enough attention towards mathematical symbols/ notations. The approach discussed in this paper transliterates digital Gujarati mathematical text into Braille text that can also be stored as text file and can be printed on the Braille printer. The methodology employed in the proposed work is developed by considering standard Braille system American Grade 0. Rules are built according to the mathematical operators and transformation table is also created. The system shows satisfactory result.

Keywords - Braille Script, Gujarati Language, Text-to-Braille (TTB), Digital Mathematical Text, Text processing, Mapping Technique
\end{abstract}

\section{INTRODUCTION}

In the world of Information Technology, where new researches, developments and inventions are witnessed in each and every field, many computer based systems are becoming available to assist people with disabilities. People with visual impairment are an integral part of the society and they can play a very significant role in the development. So if system is provided to them then it will become an aid for them in communication and interaction with sighted people. Touch and hearing are the two major senses well developed in visually impaired people then in sighted people. Braille is the system used by blind people for reading and writing, which depends on the sense of touch with finger.

\section{A. About Braille}

Braille [2] is a writing system using a series of raised dots to be read with the fingers by people who are blind or for those whose eyesight is not able to read printed material. Frenchman Louis Braille, creator of Braille, developed code for French alphabet as an improvement on night writing [8, 9, 11, 13, 34]. He published his system, which included musical notation [10], in 1829. Braille is written with the notion of cell that consists of raised dots on thick sheet of paper and it is accomplished with the help of embossing. A Braille cell has six dots arranged in the form of a rectangular grid of two dots horizontally in a row and three dots vertically in a column and due to this way of arrangement of six dots, only sixty

\section{${ }^{1}$ Smt. Tanuben \& Dr. Manubhai Trivedi College of Information Science Surat, Gujarat, India}

${ }^{2}$ Shrimad Rajchandra Institute of Management \& Computer Application, Uka Tarsadia University, Gopal Vidyanagar, Bardoli, Gujarat, India 
four different patterns of dots can be obtained. Each arrangement of dots is known as a cell [1] and will have of at least one raised dot and a maximum of six as shown in fig. $1[3,8,13,14,34]$.

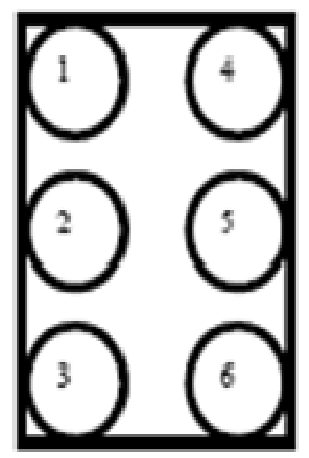

Figure 1. A Braille cell with 6 dots

\section{B. Braille Printer}

Embosser is a Braille printer used to print Braille on a special sheet of paper. Standard Braille printed document contains text of twenty five rows and each row contains forty cells and its physical dimension is approximately 11 inches by 11 inches. There is the standard for the dimension of Braille cell as printed on the Embosser [20], but in some countries it may slightly vary where they use cell of eight dots.

The Braille document can be printed either single sided or double sided. So dots of a Braille cells on the paper should be on the intersections of an orthogonal grid. In double sided printed document, the dots formed are called Recto dot and Verso dot. As verso dots are slightly shifted, so the grid of verso dots falls between the grid of recto dots [30].

\section{Gujarati Language}

Gujarati is one of the Indian languages which are derived from Devnagari script [5]. Gujarati alphabet contains overall 75 distinct legitimate and recognized shapes [4, 25], which mainly includes 59 Characters and 16 diacritics. Fifty-nine characters are divided into 10 numerical digits, 36 consonants (34 Singular and 2 Compound (not lexically though)) means ornamented sounds and 13 vowels (pure sounds). Sixteen diacritics are divided into 13 vowel and 3 other characters. In Gujarati script each character represent a syllable [20] and it is written from left to right. Consonants are called Vyanjan and Vowels are called Swar. Corresponding to each vowel, Gujarati script contains Maatras

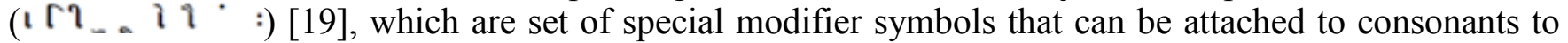
change their sound. Modifiers are placed at the top, at bottom or at bottom right part of consonant. They are attached at different positions for different consonants and they can also occur in different shapes. A character is conjunct, if two half consonants are joined [19]. So, characters in Gujarati can be the combination of consonant, vowels and diacritics.

Figure 2 shows Bharati Braille or Bhartiya Braille used for writing the Indian languages and Gujarati Braille is one of them. Punctuations as represented in Braille [6] as shown in fig. 3). 


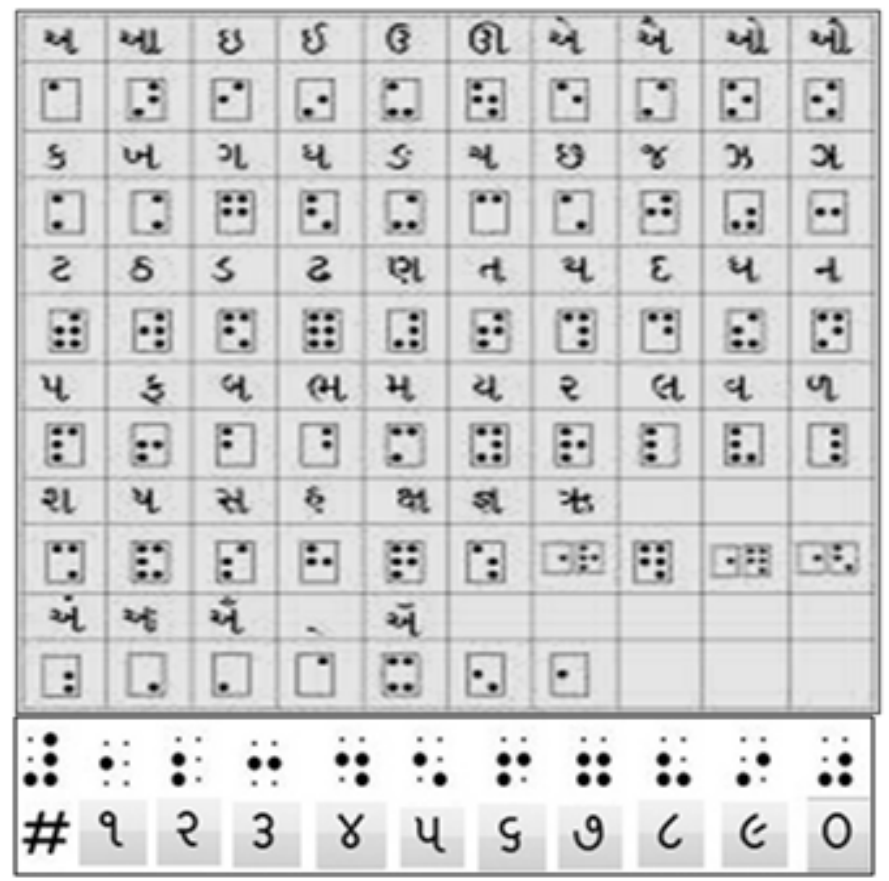

Figure 2. Gujarati Braille (Alphabets and digits - Nemeth Code)

\begin{tabular}{|c|c|c|c|c|c|c|c|c|c|}
\hline Punctuation & \multicolumn{2}{|c|}{$\begin{array}{c}\text { Comma I } \\
\text { Apostrophe }\end{array}$} & ; & : & $\begin{array}{c}1 \\
\text { (danda) }\end{array}$ & (double danda) & ! & $\begin{array}{l}\text { ?/Open } \\
\text { quote }\end{array}$ & $\begin{array}{l}\text { Close } \\
\text { quote }\end{array}$ \\
\hline Braille & \multicolumn{2}{|c|}{$\begin{array}{l}\circ 0 \\
\bullet 0 \\
0\end{array}$} & $\begin{array}{l}\circ \circ \\
\bullet \circ \\
\bullet\end{array}$ & $\because \circ$ & $\begin{array}{l}0 \\
\bullet \\
0\end{array}$ & $\begin{array}{lll}\circ & \circ & \circ \\
\bullet \bullet & \bullet & \bullet\end{array}$ & $\because \div$ & $\begin{array}{ll}\circ & 0 \\
\bullet & 0 \\
\bullet & \bullet\end{array}$ & $\begin{array}{ll}0 & 0 \\
\circ & :\end{array}$ \\
\hline Punctuation & Accent & Hyphen & $\mathrm{Da}$ & & Pointing & Asterisk & Italics & I & ) \\
\hline Braille & $\begin{array}{ll}0 & \bullet \\
0 & 0 \\
0 & 0\end{array}$ & $\begin{array}{ll}0 & 0 \\
0 & 0 \\
- & -\end{array}$ & $\begin{array}{ll}0 & 0 \\
0 & 0 \\
\bullet & -\end{array}$ & $\begin{array}{ll}0 & 0 \\
0 & 0 \\
\bullet & \bullet\end{array}$ & $\begin{array}{ll}0 & 0 \\
0 & 0\end{array}$ & $\begin{array}{llll}0 & 0 & 0 & 0 \\
0 & \bullet & 0 & \bullet \\
\bullet & \bullet & 0\end{array}$ & $\begin{array}{ll}\circ & \bullet \\
\circ & \circ \\
\circ & \bullet\end{array}$ & $\because \bullet$ & 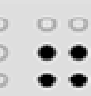 \\
\hline
\end{tabular}

Figure 3. Punctuations in Braille

\section{Literature Review}

The overviews of some of the literatures related to the conversion of various types of scripts to Braille are as follows:

A. King [27] have develop project on text and Braille computer translation using Java programs. It uses existing finite state machine, context matching and set of translation rules. It translates different grades of Braille contraction. C. Vignesh and M. Senthil Kumaran [39] have work on conversion of printed document into Braille. Image processing technique is used to convert optical image into editable form and from it, it is converted into corresponding Braille text. They have also included Text to Speech module to convert English text to speech. S. A. Hossain, L. A. Biswas and Md. I. Hossain [15][16] have presented Regular Expression for Bangla to Braille Machine Translator using deterministic finite automata, structured and state elimination method to generate and validate regular expression. The work is tested on language rules and it gives satisfactory result but generate very long expression. F. Md. Mahbub-ul-Islam [29] have proposed computational model for Bangla Text to Braille Translation using Deterministic Finite Automata (DFA) and other software architecture. They have used open source technology for implementation. The system is tested on Bangla Unicode-based text contents and generated Braille code is verified after printing. C. Salah and A. Ranjith Ram [33] have discussed Malayalam text to Braille transliteration which transliterates scanned books and magazines into Braille. They have used optical character recognition and Braille mapping technique. Further in another paper [32] they have also described issues related to the transliteration of Malayalam text into Braille. O. Khan 
Durrani and K. C. Shet [26] have described an architecture for transcribing Braille from optically recognized Indian language. The main module of the system is OCR module that supports portability and scalability. They have also discussed properties of Braille and Indian scripts and also the importance and necessity of the system. Along with it, they have also provided the work carried out in Indian languages. Finally, they have clearly explained the System architecture followed by conclusion and future work. N. B. Jariwala and B. Patel [20] have worked on the transliteration of digital Gujarati text to Braille. They have used transformation tables and Mapping technique for transliteration. Plain Gujarati text is inputted to the system then according to translation rules and mapping technique corresponding Braille character is lookup from transformation table, and then the character is stored into the text file which can be printed on the Braille printer. The system is tested on the text collected from digital newspapers and chapters collected from blind student school. The system gives satisfactory result. Marc Bitter [7] has done comparative research on Dutch Braille codes that supports mathematics. The methods used are literature research and interviews to compare different Braille codes and their complexity for mathematics formulas. S. Maddox [28] has described several standards to represent mathematical Braille. Author has discussed complexities and challenges to represent mathematical notations into Braille. Author has also described various software tools available for the conversion to Text to Braille and their limitations for the conversion of Mathematical text to Braille. M. Hersh [17] described the difficulties in deriving math representations for blind people. Author also discussed the approach based on Braille and speech, and issues relating to providing support for math analysis. M. Jarmar [21] has develop software that provides accessibility in mathematical documents to blind and visually impaired people. Author has also discussed on existing solutions in this approach. Author has tried to implement Czech Braille output module for UMCL library, but as UMCL itself is erroneous, So proper solution was not been developed. J. A. Gardner, L. Ungier and J. J. Boyer [12] have worked on Braille math for Tiger embossers with Tiger Formatter. It works well with basic equations in English language but still advanced math expressions are to be tested. A. I. Karshmer and C. Bledsoe [23] have described new approaches to offer access of math to blind students, basic problems in representing math in Braille and historical solutions. P. B. Stanley and A. I. Karshmer [35] have worked on translating MathML into Nemeth Braille Code. They need to translate equations into MathML through equation editor; translated statement is saved and then translated into Nemeth Code. So here they need Math equation in MathML then only it can be converted into Braille. M. Victor and A. Dominique [37] [38] have developed a project for translating Mathematics into Braille. Input to the project is the equations written in LATEX or MathML and output is the French Mathematics Braille. A. Karshmer, G. Gupta and E. Pontelli [24] have discussed on the accessibility of the math text to the blind people. They have described challenges in converting math text into Braille. They discussed on Braille codes and the existing solutions. But still according to their survey full-fledged solution does not exists that convert mathematical text to Braille.

We came across many literatures in various languages that convert text to Braille including Gujarati language [20]. Researchers are working on the conversion of Mathematical text to Braille for different languages, but due to the complexities and challenges in conversion of mathematical text to Braille, only partial solution exists and all approaches have their own limitations [24, 28]. And still no work is found for the transliteration of Gujarati Mathematical Text to Braille. So we aim to extend the work discussed in [20] for the conversion of Gujarati Mathematical Text (UTF-8 format) into printable Braille in both the standards: Nemeth Code (Asian language) and Literary code (Western language). Text processing method i.e. transformation of text from one format to another is used and along with it Character mapping algorithm is designed to resolve the problem. Let's see it in detail.

\section{TRANSLITERATION TOOL}

\section{A. Braille - Mathematical Symbols and digits}

Mathematical text can be represented using several different standards [28] such as UK RNIB, Dotplus, Nemeth, GS Braille and Literary. Commonly used standard for Asian languages are: Nemeth Code (see fig. 4) and Literary Code (see fig. 5). The Nemeth code for Braille Mathematics was designed by Dr. Abraham Nemeth in 1946 and it was accepted as a standard for representing mathematics and 
science expressions in Braille in 1952 [31]. Literary code is the Unified English Braille Code (UEBC) standard [36], developed to represent English mathematical text. Figure 6 represents various Mathematical symbols in Braille.

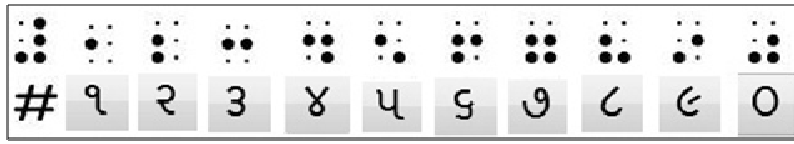

Figure 4. Nemeth Braille Code

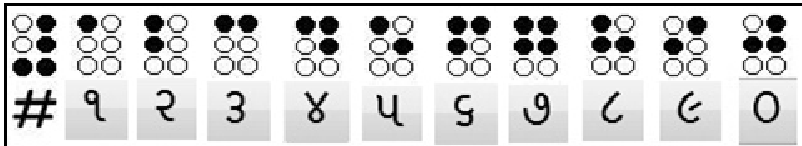

Figure 5. Literary Braille Code

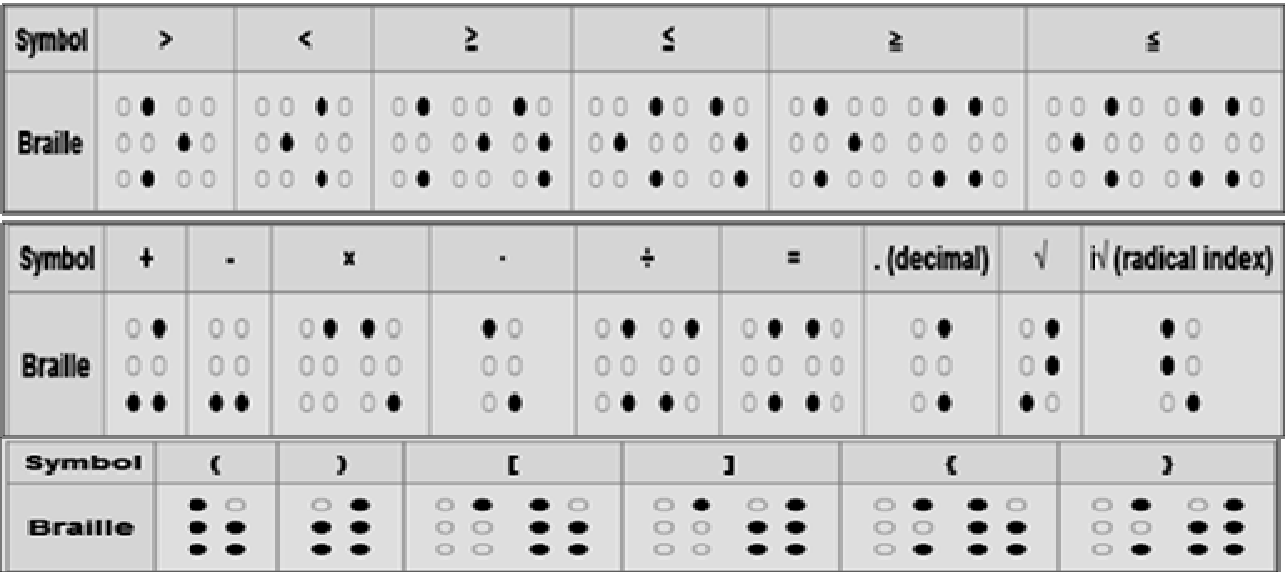

Figure 6. Mathematical Symbols in Braille

There are many challenges and complexities that are needed to be consider for the conversion of Mathematical text to Braille. To represent mathematics in Braille many special characters and modifiers need to be added in the notations, which increases the size and complexity of the mathematical text [7]. Linear form of mathematical equation is needed to represent it into Braille and it is very difficult to convert any mathematical notation into linear form $[7,28,21]$.

\section{B. Character Mapping}

Transformation table is created which contains Gujarati character, Mathematical symbols and its corresponding Braille character. So character mapping technique is used for mapping the characters from the inputted text to the characters in transformation table for the conversion of Gujarati Mathematical Text into Braille. Table 1 shows the mapping of Gujarati digits to Nemeth and Literary Code, and other mathematical symbols to the pins in the Braille printer, its meaning, and corresponding printable Braille character (ASCII) according to Standard American Grade 0 [18].

Table -1 Standard Braille translation rules American grade 0

\begin{tabular}{|c|c|c|c|}
\hline $\begin{array}{c}\text { Braille Pins in } \\
\text { Embosser }\end{array}$ & $\begin{array}{c}\text { ASCII } \\
\text { Charact } \\
\text { er }\end{array}$ & $\begin{array}{c}\text { Braille } \\
\text { characte } \\
\text { r }\end{array}$ & Meaning \\
\hline \multicolumn{4}{|c|}{ Nemeth Code } \\
\hline Braille p2 & "1" & $: \therefore$ & One "1", ? \\
\hline Braille p23 & "2" & $: \therefore$ & Two "2", ? \\
\hline
\end{tabular}




\begin{tabular}{|c|c|c|c|}
\hline Braille p25 & "3" & $\because-$ & Three "3", 3 \\
\hline Braille p256 & "4" & $-=$ & Four "4", $\gamma$ \\
\hline Braille p26 & "5" & $\because$ & Five "5", ૫ \\
\hline Braille p235 & "6" & $:-$ & Six “6”, G \\
\hline Braille p2356 & "7" & $\because 0$ & Seven “7”, 9 \\
\hline Braille p236 & "8" & & Eight " 8 ", c \\
\hline Braille p35 & "9" & $a$ & Nine "9",, \\
\hline Braille p356 & “0” & & Zero “0”, 0 \\
\hline \multicolumn{4}{|c|}{ Literary Code } \\
\hline Braille p1 & "a" & 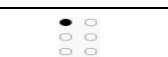 & One "1", ? \\
\hline Braille p12 & "b" & $:$ & Two "2", ? \\
\hline Braille p14 & "c" & & Three "3", 3 \\
\hline Braille p145 & "d" & $\because$ & Four "4", $\gamma$ \\
\hline Braille p15 & "e" & & Five "5", ૫ \\
\hline Braille p124 & "f" & & Six “6”, 马 \\
\hline Braille p1245 & "g" & & Seven “7”, 9 \\
\hline Braille p125 & "h" & & Eight "8", c \\
\hline Braille p24 & "i”" & 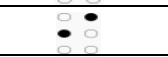 & Nine "9", \\
\hline Braille p245 & "j;" & $\bullet$ & Zero “0”, 0 \\
\hline \multicolumn{4}{|c|}{ Arithmetic Operators } \\
\hline Braille p346 & " +" & & Plus sign "+" \\
\hline Braille p36 & “"_"“ & & Minus sign “_”“ \\
\hline Braille p4, p16 & “@”,"*” & & $\begin{array}{l}\text { Multiplication } \\
\text { sign " } \mathrm{x} \text { " }\end{array}$ \\
\hline Braille p46, p34 & “.",“/” & & Division sign " $\div$ ” \\
\hline \multicolumn{4}{|c|}{ Comparison operators } \\
\hline Braille p46, p2 & ".,","1" & & $\begin{array}{l}\text { Greater than sign } \\
\text { ">" }\end{array}$ \\
\hline Braille p5, p13 & “"’”,’k" & $\bullet$ & Less than sign " $<$ " \\
\hline Braille p46, p13 & “.","k" & 0 & Equal to sign "=" \\
\hline $\begin{array}{l}\text { Braille p46, p5, } \\
\text { p156 }\end{array}$ & “.,, ",",,",": & & $\begin{array}{c}\text { Greater than equal } \\
\text { to " } \geq "\end{array}$ \\
\hline $\begin{array}{c}\text { Braille p5, p13, } \\
\text { p156 }\end{array}$ & $\begin{array}{c}\text { ،"',"'k"," } \\
\text { :" }\end{array}$ & $\begin{array}{l}\bullet \\
\bullet: \circ: \\
\bullet\end{array}$ & $\begin{array}{l}\text { Less than equal to } \\
\text { " }\end{array}$ \\
\hline \multicolumn{4}{|c|}{ Brackets } \\
\hline Braille p12356 & “( $"$ & & $\begin{array}{c}\text { Opening } \\
\text { Parenthesis “("“ }\end{array}$ \\
\hline Braille p23456 & “)” & & $\begin{array}{c}\text { Closing } \\
\text { Parenthesis")" }\end{array}$ \\
\hline $\begin{array}{c}\text { Braille p4, } \\
\text { p12356 }\end{array}$ & “@”,"“(“ & $\bullet$ & $\begin{array}{c}\text { Opening Square } \\
\text { Bracket "[ }\end{array}$ \\
\hline $\begin{array}{c}\text { Braille p4, } \\
\text { p23456 }\end{array}$ & “@”, “)” & & $\begin{array}{l}\text { Closing Square } \\
\text { Bracket "]"' }\end{array}$ \\
\hline Braille p46, & "?", "“(" & $: \vdots:$ & Opening Curly \\
\hline
\end{tabular}




\begin{tabular}{|c|c|c|c|}
\hline p12356 & & & Bracket “ $\{“$ \\
\hline $\begin{array}{l}\text { Braille p46, } \\
\text { p23456 }\end{array}$ & “.”, “)” & $\bullet$ & $\begin{array}{l}\text { Closing Curly } \\
\text { Bracket "\}" }\end{array}$ \\
\hline \multicolumn{4}{|c|}{ Set Theory Symbols } \\
\hline $\begin{array}{l}\text { Braille p46, } \\
\text { p146 }\end{array}$ & “.", “\%"\% & $:$ & Intersection " $\cap$ " \\
\hline $\begin{array}{c}\text { Braille p46, } \\
\text { p346 }\end{array}$ & “.”, “+” & & Union "U" \\
\hline Braille p4, p15 & “@”, “e” & & $\begin{array}{lll}\text { an } & \text { element of } \\
" \in, & \end{array}$ \\
\hline $\begin{array}{l}\text { Braille p456, } \\
\text { p5, p13, p156 }\end{array}$ & 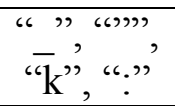 & 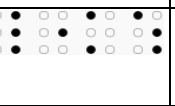 & Subset " $\subseteq "$ \\
\hline $\begin{array}{l}\text { Braille p456, } \\
\text { p5, p13 }\end{array}$ & 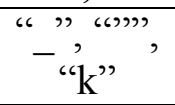 & & Proper subset " $\subset$ " \\
\hline \multicolumn{4}{|c|}{ Geometry Symbols } \\
\hline $\begin{array}{l}\text { Braille p1246, } \\
\text { p246 }\end{array}$ & "\$", "["6 & & Angle " $\angle$ " \\
\hline $\begin{array}{l}\text { Braille p1246, } \\
\text { p2345 }\end{array}$ & "\$", “t” & & Triangle " $\Delta$ " \\
\hline $\begin{array}{l}\text { Braille p1246, } \\
\text { p256 }\end{array}$ & “\$”, “4” & & Square “ $\square ”$ \\
\hline $\begin{array}{l}\text { Braille p1246, } \\
\text { p1235 }\end{array}$ & $" \$ ", r "$ & $:$ & Rectangle “ $\square$ " \\
\hline $\begin{array}{l}\text { Braille p1246, } \\
\text { p1234 }\end{array}$ & “\$”, “p” & & Perpendicular "l" \\
\hline $\begin{array}{l}\text { Braille p1246, } \\
\text { p123 }\end{array}$ & “\$”, “1” & & Parallel "“|"' \\
\hline $\begin{array}{c}\text { Braille p1246, } \\
\text { p14 }\end{array}$ & “\$”, “c” & & Circle " $\bigcirc "$ \\
\hline \multicolumn{4}{|c|}{ Braille indicators } \\
\hline Braille p456 & “"” & & Punctuation \\
\hline Braille p45 & $" \bar{\wedge} "$ & : & Superscript \\
\hline Braille p56 & “";" & 8 & Subscript \\
\hline Braille p5 & ליוים" & 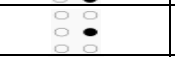 & Beginning \\
\hline Braille p123456 & $"="$ & $::$ & Omission \\
\hline Braille p246 & "[" & $\bullet$ & Cancel (open) \\
\hline Braille p12456 & "]" & $\vdots \vdots$ & Cancel (close) \\
\hline Braille p126 & "<" & $=$ & Directly Over \\
\hline Braille p146 & "\%" & & Directly under \\
\hline Braille p12456 & "]" & $\because:$ & Termination \\
\hline \multicolumn{4}{|c|}{ Roman Numerals } \\
\hline Braille p6, p24 & ",", “i”" & $\vdots \vdots$ & One "I" \\
\hline $\begin{array}{l}\text { Braille p6, } \\
\text { p1236 }\end{array}$ & “,”, “v” & & Five "V" \\
\hline Braille p6, & ",", “x” & $\vdots$ & Ten "X" \\
\hline
\end{tabular}




\begin{tabular}{|c|c|c|c|}
\hline p1346 & & & \\
\hline Braille p6, p123 & “,", “l”' & $\bullet$ & Fifty "L" \\
\hline Braille p6, p14 & ",", “c"c" & $\cdot$ & Hundred "C" \\
\hline Braille p6, p134 & “,", “m” & & Thousand "M" \\
\hline \multicolumn{4}{|c|}{ Other Symbols } \\
\hline Braille p46 & "." & & Decimal point “.” \\
\hline Braille p3456 & “\#” & & Digit prefix “\#” \\
\hline Braille p6 & “," & & Maths full stop "." \\
\hline Braille $p$ & “" “6 & $<$ space $>$ & 32 “، \\
\hline $\begin{array}{c}\text { Braille p46, } \\
\text { p1234 }\end{array}$ & “.”, “p” & & Phi " $\pi$ " \\
\hline Braille p345 & $">"$ & $:$ & Square root " $\sqrt{ }$ " \\
\hline Braille p4, p356 & "@”, “0” & $\because \because \vdots$ & Percentage "\%" \\
\hline
\end{tabular}

As per the requirements Braille printer is to be configured and translation rules have to be modified. But, as shown in table 1, in the proposed work American Grade 0, standard Braille translation rules of the embosser i.e. MIT specified in the User Manual of Index Braille Embosser [18] are used for mapping the Braille characters to its ASCII character.

\section{Algorithm}

The transliteration tool developed focuses on both types of code (Nemeth and Literary) and convert Mathematical Text to Braille. The focus is done on the conversion of decimal numbers, arithmetic operations, and comparison operations, various types of brackets, oblique sign, unit representation and roman numbers, geometry notations and set theory symbols.

There are various rules defined to convert Mathematical text to Braille [22]. The rules are as follows:

- Gujarati mathematical text is represented using Nemeth Braille Code.

- Before writing number, number prefix (\#) $\vdots$ is required to represent that the following cell is digit and not character.

- Decimal point is separated by $\vdots \quad \operatorname{dot}($.

- No space (before and after) is to be specified to represent $+,-, \mathrm{x}, \div$ symbols.

- There must be one space before and after the comparison symbols $(<,>,=)$.

- If negative sign (-) is represented in the starting of the equation then it is necessary to put number prefix before the number.

- At the time of representing units such as Rs, P, cm etc. if there is dot at the end i.e. Rs. Then English letter prefix : $:$ is to be placed and if it doesn't contain dot at the end i.e. Rs then there is no need to place English Letter prefix.

- To represent Roman letters, if there is single letter then single capital prefix : $:$ is to be placed and if there are more than one letter then two capital prefix $::$ is to be placed.

- It is necessary to use shape indicator $(\$):-$ before specifying shapes (for example, in geometry notations before using angle symbol $:$, it is mandatory to add shape indicator $\left.::-{ }^{\circ}\right)$

- No space is to be specified before percentage (\%)

- Special Braille indicators (see table 1) need to be specified before specifying superscript and subscript and to remove the effect of it first baseline Braille indicator is to be added then the text is to be written. 
Steps of the algorithm are as follows:

Step 1: Open the file which contains mathematical text.

Step 2: Read whole content of the file and store it in an array.

Step 3:Convert all elements of array into its decimal equivalent (UTF-8)

Step 4: Traverse the array containing mathematical text to check following conditions specified in step 5 to 8 .

Step 5:If the element is Digit then according to the rules number prefix is concatenated and equivalent Braille character of both are appended to another array.

Step 6: If the element is Gujarati character then according to the rules convert it to its equivalent Braille character and append it to array.

Step 7: If the element is English character then check the next character, if it is again English character then add English letter sign accordingly and convert to its equivalent Braille character and append it to array

Step 8: If element is mathematical operator then according to the rules of operators convert it and append it to the array.

If needed, according to the rules, Braille indicators and special modifiers are also added to the array.

Step 9: Repeat the steps 5 to 8 till the end of array (array if decimal equivalent: UTF-8) is reached.

Step 10: The array of Braille characters is stored into the text file.

The file created after the execution of the algorithm contains the character that can be directly printed on the Braille Printer (Embosser). The algorithm described is totally based on mapping technique and text processing.

\section{TESTING AND RESULT}

The mathematical text to Braille system is tested on the text collected from the document from the maths teacher of Andhjan Shala (Blind Student School), Surat. The documents transliterated from the transliteration tool are verified by the experts (Braille teacher) and it shows that algorithm works perfect and gives satisfactory result for the decimal numbers, arithmetic operations, comparison operations, various types of brackets, oblique sign, units representation and roman numbers, geometry notations, set theory symbols etc.

Figure 7 shows sample transliteration of mathematical text to Braille. It contains 3 boxes. Box on left side displays original mathematical text. Top box on right display the transliteration in the Nemeth Code and bottom box on right display the transliteration in Literary Code. 


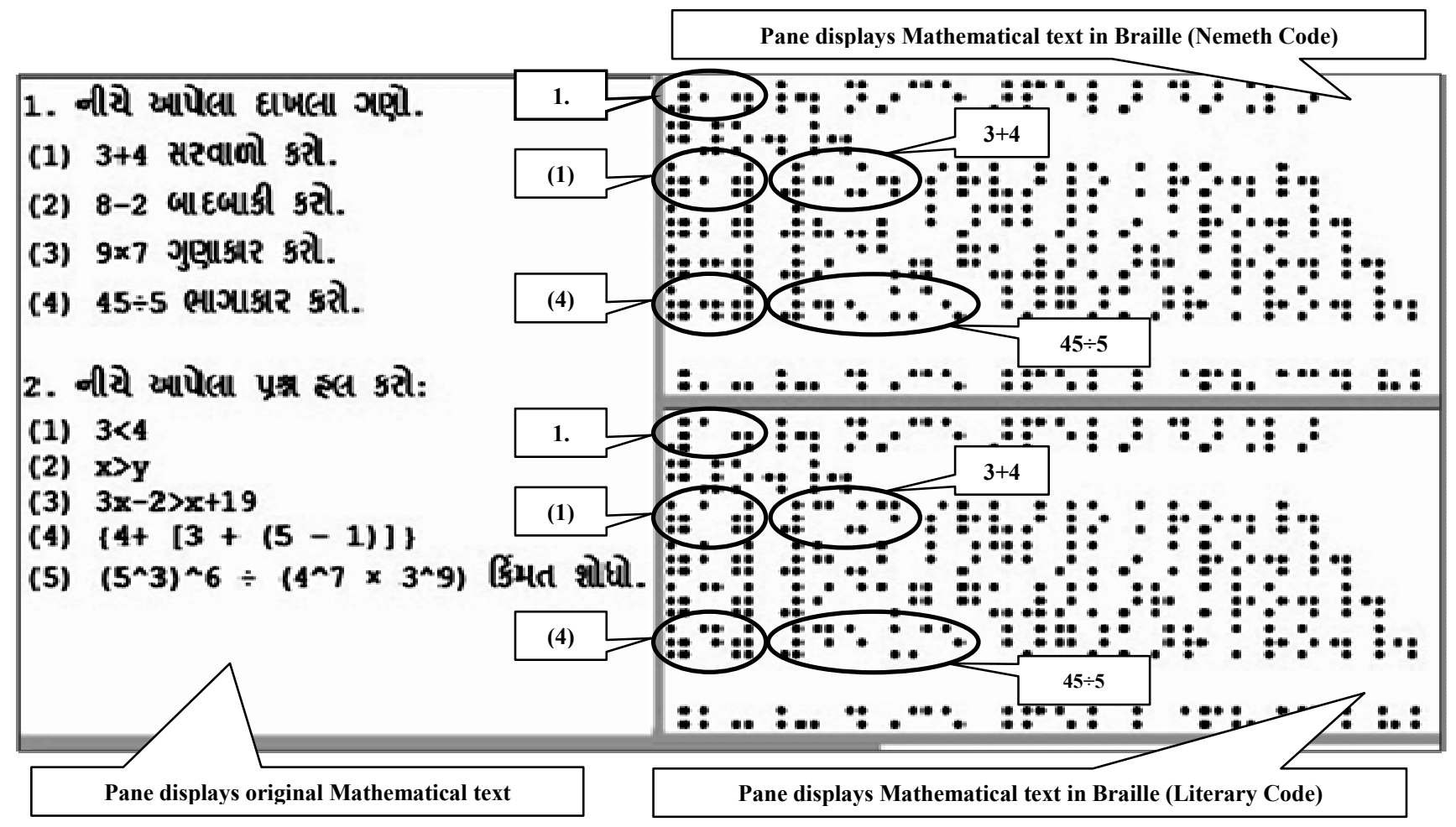

Figure 7. Sample Transliteration through the tool

IPA representation of original Gujarati mathematical text (shown in fig. 7) is as follows:

1. $</$ niche/ $></$ apela/ $></$ dakhəla/ $></$ gəno/ $>$.

(1) $3+4</$ sərəvalo $/></$ kəro $/>$.

(2) $8-2</$ badbaki $/></$ kəro $/>$.

(3) $9 \times 7</$ gunakar $/><$ kəro/ $>$.

(4) $45 \div 5</$ bhagakara/ $><$ /kəro/ $>$.

2. $</$ niche/ $></$ apela/ $></$ prafno/ $></$ həl $/></$ kəro/ $>$.

(1) $3<4$

(2) $\mathrm{x}>\mathrm{y}$

(3) $3 x-2>x+19$

(4) $\{4+[3+(5-1)]\}$

(5) $\left(5^{\wedge} 3\right)^{\wedge} 6 \div\left(4^{\wedge} 7 \times 3^{\wedge} 9\right)</$ kimmətə/ $/></$ Jodho/ $>$

\section{IV.CONCLUSION}

The system discussed in the paper transliterates Gujarati Mathematical Text to Printable Braille and store it in a text file which can further be printed on the Embosser. The proposed work is fully tested and verified by experts. It gives satisfactory results. It is an attempt to develop low cost technology to assist visually impaired people. It act as an aid for those who want to learn mathematical Braille as it shows mathematical text in Braille as well as original text at the same time. The transliteration tool is deployed at blind student school and it shows that there is an improvement in the way of learning mathematical Braille by visually impaired students. 


\section{ACKNOWLEDGEMENT}

We are grateful towards Gujarat Council of Science \& Technology (GUJCOST) for funding the Minor Research Project for the transliteration of Gujarati Text to Braille. We would like to express our warm and sincere thanks towards trustee Shri. Anand Chokhavala, the Principal Ms. Manisha Gajjar, and teachers Mrs. Falguni Panchal and Mrs. Jasmina Dalal of Ambaben Maganlal Andhjan Shala, Surat for their co-operation by supporting us in learning Braille and by providing necessary resources needed for the work. We would also like to thank Dr. Naren Burade to motivate us for the work on Braille language for visually impaired people

\section{REFERENCES}

[1] Acharya-Multilingual Computing for Literacy and Education [Online] Available: www.acharya.gen.in/ Introduction to Braille.htm.

[2] S. Al-Salman, "A Bi-directional Bi-Lingual Translation Braille System", J. King Saud University Computer \& Information Science, vol. 20, pp. 13-29, 2008.

[3] S. D. Al-Shamma and S. Fathi, "Arabic Braille Recognition and Transcription into Text and Voice", In Proceedings of 5th International Biomedical Engineering conference, pp. 227-231, December 2010.

[4] Babu Suthar - Gujarati-English Learner's Dictionary.

[5] M. J. Baheti, K. V. Kale and M. E. Jadav, "Comparison of Classifiers for Gujarati Numeral Recognition”, International Journal of Machine Intelligence, vol. 3, pp. 160-163, 2011.

[6] Bharati Braille- The online encyclopedia [Online] Available: http://www.Wikipedia.com/ Bharati Braille - Wikipedia, the free encyclopedia.htm

[7] M. Bitter, "Braille in Mathematics Education", Thesis, April 2013.

[8] P. Blenkhorn, "A System for Converting Braille into Print”, IEEE Transactions on Rehabilitation Engineering, vol. 3, pp. 215-221, June 1995.

[9] Braille- The online encyclopedia [Online] Available: http://www.Wikipedia.com/ Braille Wikipedia, the free encyclopedia.htm

[10]L. Braille, "Method of Writing Words, Music, and Plain Songs by Means of Dots, for Use by the Blind and Arranged for Them", 1829.

[11] A. Chaudhary, P. Garg and A. Agarwal, "Using Rotation Method for Removal of Misalignment of Scanned Braille Pattern", In Proceedings of the Second International Conference on Advances in Computing, Control and Communication, pp. 71-75, 2012.

[12] J. A. Gardner, L. Ungier and J. J. Boyer, "Braille Math Made Easy with the Tiger Formatter".

[13] S. Halder, A. Hasnat, A. Khatun, D. Bhattacharjee and M. Nasipuri, "Development of Bangla Character Recognition (BCR) System for Generation of Bengali Text from Braille Notation", International Journal of Innovative Technology and Exploring Engineering, vol. 3, pp. 5-10, June 2013.

[14] M. Y. Hassan and A. G. Mohammed, "Conversion of English Characters into Braille Using Neural Network”, Iraqi Journal of Computers, Communication, Control and Systems Engineering, vol. 11, pp. 30-37, January 2011.

[15] S. A. Hossain, L. A. Biswas and Md. I. Hossain, "Regular Expression for Bangla - 2 - Braille Machine Translation", International Conference on Advances in Engineering and Technology, pp. 54-57, March 2014. 
[16]S. A. Hossain, L. A. Biswas and Md. I. Hossain, "Analysis of Bangla - 2 - Braille Machine Translation", International Conference on Computer and Information Technology, pp. 300-304, December 2014.

[17] M. Hersh, "Maths for Blind People: Not reinventing the wheel... Crooked".

[18] Index Braille 4x4 Embosser User manual [Online] Available: http://www.indexbraille.com/enus/support.

[19]N. B. Jariwala and B. Patel, "Multi-Oriented Gujarati Characters Recognition: A Review", International Journal of Research in Computer Science and Information Technology, vol. 2, pp. 1-5, March 2014.

[20]N. B. Jariwala and B. Patel, "Transliteration of Digital Gujarati Text into Printable Braille", In Proceedings of 5th IEEE International Conference on Communication System and Network Technologies, pp. 572-577, April 2015.

[21] M. Jarmar, "Conversion of Mathematical Documents into Braille". Thesis.

[22]H. Joshi, "Braille Mathematics Code for India", Book.

[23] A. I. Karshmer and C. Bledsoe, "Access to Mathematics by Blind Students". In Proceedings of ICCHP, pp. 471-476, 2002.

[24] A. Karshmer, G. Gupta and E. Pontelli, "Mathematics and Accessibility: A Survey", February 2007.

[25]M. Kayasth and B. Patel, "Offline Typed Gujarati Character Recognition", National Journal of System and Information Technology, vol. 2, pp. 73-82, 2009.

[26]O. Khan Durrani and K. C. Shet, "A New Architecture for Braille Transcription from Optically Recognized Indian Languages", International CALIBER, February 2005.

[27] A. King, "Text and Braille Computer Translation”, dissertation, September 2001.

[28] S. Maddox, "Mathematical Equations in Braille". MSOR connections, vol. 7, pp. 45-48, May 2007.

[29] Md. F. Mahbub-ul-Islam, A. I. Khan, Md. O. Gani, S. Azam and S. A. Hossain, "Computational Model for Bangla Text to Braille Translation", In Proceedings of 2nd International Conference on Computer Processing of Bangla, Independent University Bangladesh, February 2011.

[30] J. Mennens, L. V. Tichelen, G. Francois and J. L. Engelen, “Optical Recognition of Braille Writing Using Standard Equipment”, IEEE Transactions on Rehabilitation Engineering, vol. 2, pp. 207-212, December 1994.

[31]Nemeth Braille - The Online encyclopedia [Online] Available: https://en.wikipedia.org/wiki/Nemeth_Braille

[32] C. Salah and A. Ranjith Ram, "Issues in Transliterating Malayalam Text into Braille", International Journal of Engineering Research and Technology, vol. 4, pp. 1367-1371, May 2015.

[33]C. Salah and A. Ranjith Ram, "A Review Paper on Malayalam text to Braille Transliteration", International Journal of Current Engineering and Technology, vol. 5, pp. 2312-2315, August 2015.

[34]M. Singh and P. Bhatia, "Automated Conversion of English and Hindi Text to Braille Representation", International Journal of Computer Applications, vol. 4, pp. 25-29, July 2009.

[35]P. B. Stanley and A. I. Karshmer, "Translating MathML into Nemeth Braille Code", In Proceedings of ICCHP, pp. 1175-1182, 2006.

[36]Unified English Braille [Online] Available: https://en.wikipedia.org/wiki/ Unified_English_Braille.

[37] M. Victor and A. Dominique, "A Transcription Tool for Mathematical Braille", In Proceedings of AAATE'03 IOS Press, pp. 481-485, 2003.

[38] M. Victor and A. Dominique, "Automatic Translator for Mathematical Braille", In Stephanidis, C., Ed.: Universal Accessing HCI-Inclusive design in the Information Society, pp. 1335-1339, 2003. 
[39]C. Vignesh and M. Senthil Kumaran, "Optical Character Recognition for Visually Challenged Persons", International Journal of Emerging Technology in Computer Science \& Electronics, vol. 14, pp. 1-5, April 2015. 